\title{
Fixed And Growth Mindset In Education And How Grit Helps Students Persist In The Face Of Adversity
}

Aaron Hochanadel, MBA, Kaplan University, USA Dora Finamore, EdD, Kaplan University, USA

\begin{abstract}
Students face a wealth of challenges in college for example a lack of support, sometimes making it difficult to persevere. However, in an academic environment that teaches grit and fosters growth, students can learn to persist. Those who believe intelligence is fixed and cannot be changed exert less effort to succeed. Students who persevere when faced with challenges and adversity seem to have what Angela Duckworth calls, grit. This is the idea behind a growth mindset in learning according to Dweck (1999, 2007, 2010) and Duckworth, Peterson, Matthews, and Kelly (2007). Grit can be defined as “...passion and perseverance for long-term goals..." (Frontiers In Psychology, 2014). One grit effect study was conducted in collaboration with the U.S. Army and the University of Pennsylvania to create predictors of retention.
\end{abstract}

The purpose of this present work is to explore researched competencies related to persistence in reaching academic goals, review literature in grit and growth mindset related to learning and persistence, and examine what educators can do to foster grit and a growth mindset. Recommendations for increasing persistence and grit in college students will be provided.

Keywords: Grit; Retention; Growth Mindset; Online Education

\section{INTRODUCTION}

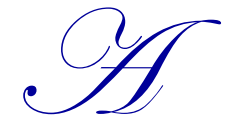

s a seventh grade math teacher in New York City, Angela Lee Duckworth noticed how some students were outperforming others, but she found some unexpected results after several years. After calculating scores and assigning grades, she realized that some students with the highest IQs did not have top grades, and some students with lower IQs were some of the best performers, thus her decision to return to graduate school and begin research into motivation for how and why students persist to reach academic goals and others do not. Her studies explored education from a motivational and psychological standpoint instead of one of the most common measurement across schools - IQ test scores. The one question to undergird her entire research study was, "Who is successful here and why?" Duckworth (2013, April) The key to success? Grit [Video File]. Retrieved from http://www.ted.com/talks/angela_lee_duckworth_the_key_to_success_grit\#t-357357. Duckworth (2007) began to review several studies in a variety of industries. At West Point, she studied which military cadets stayed in military training and which ones dropped out. She also analyzed results from the National Spelling Bee to determine which children were more likely to advance and which ones did not. Duckworth partnered with a private corporation and surveyed managers to determine which sales representatives would be more likely to leave the company and which ones would be successful. She also analyzed data from first-year inner city elementary school teachers to measure that would not return after that first year and, of those that would, which ones would be most effective; making sure students met their outcomes. Out of all the studies across the different industries, one characteristic emerged as a significant predictor of success - Grit. Duckworth defines Grit as, “...passions and persistence for long-term goals" (Duckworth \& Quinn, 2009, p 166). 
As Duckworth's research expanded, she learned that Carol Dweck, PhD - Stanford University, was conducting studies to determine how a fixed belief that failure is permanent could prevent students from academic success. Duckworth concluded that grit could be developed by having a "growth mindset." Dweck's studies were demonstrating that teaching young students how the brain is capable of change when faced with challenges helped them persevere and develop a growth mindset.

\section{Grit Measured At West Point}

Each year, over 10,000 students apply to West Point, but only 4,000 are accepted (Duckworth, 2007). In addition to the standard testing, West Point has additional admission requirements for prospective students. The school requires ACT Plus writing, a physical assessment, and a qualifying medical exam as part of the admissions process. Duckworth's 2007 study was based upon survey results from 1,218 cadets. The Grit predictor study was based on a freshmen summer training program. With the constant demands placed on cadets and abrupt changes allowing them to make quick decisions during a high-pressure situation, Duckworth wanted to find out why and how some succeeded and others failed (Perkins-Gough, 2013).

\section{Fixed And Growth Mindset In Education: How Grit Helps Students Persist In The Face Of Adversity}

Students who value effort are said to have a growth mindset. They perceive ability as a malleable skill. Those who think intelligence is inherent and unchangeable exert less effort to succeed and have a fixed mindset (permanent capacity). Students who persevere when faced with challenges and adversity seem to have what Duckworth calls grit. This is the idea behind a growth mindset in learning (Dweck, 1999, 2007, 2010; Duckworth, 2007). Vandewalle (2012) found, "When one holds a fixed mindset, that initial information becomes an anchor that impedes the likelihood of engaging in counterfactual thinking" ( $p$ 304). It also seems that goal orientation alone is not enough to predict learning. De Meuse, Guangrong, and Hallenbeck (2010) did not find evidence in the literature of a statistically significant relationship between learning goal orientation and learning. Duckworth and EskreisWinkler (2013) have further demonstrated, "In our cross-sectional analyses, grit increases monotonically throughout adulthood. One possibility is that people have a growing appreciation of the efficacy of effort as they age." (p.174181)

Dweck's theory may hold promise for those who struggle, especially in the online college environment. The low rates of retention may, in part, be due to having a fixed mindset and lack of grit. In earlier research, Peterson and Seligman (1984) found that certain associations (positive or negative) are made when faced with challenges and people act on those ideas in various ways, expecting the same results. Chiu et al. (1997) concluded that when those with a fixed mindset are asked to determine future behavior based on specific situations, they perceive subsequent behavior based on past experiences and are not able to see change. This is in keeping with Nolen-Hoeksema, Girgus, \& Seligman's (1986) theoretical stance on learned helplessness, learned optimism and causal attributions or explanatory style. Dweck further asserts, "Individuals with a fixed mindset believe that their intelligence is simply an inborn trait - they have a certain amount and that's that. In contrast, individuals with a growth mindset believe that they can develop their intelligence over time" (2010, p. 16).

Duckworth and Dweck worked together to better understand why some students succeed at persisting, in order to reach academic goals, and others give up. Duckworth states, "Grit is not just having resilience in the face of failure, but also having deep commitments that you remain loyal to over many years." (Perkins-Gough, D., 2013) Duckworth conducted studies to determine what grit is and how it affects perseverance and resilience. In her seminal study on grit, she found that cadets at West Point were able to reach their goals based on grit, more than other characteristics. Duckworth, Peterson, Matthews, and Kelly (2007) “... introduced the construct of grit, defined as trait-level perseverance and passion for long-term goals, and showed that grit predicted achievement in challenging domains over and beyond measures of talent" (Duckworth \& Quinn, 2009, p. 166). 


\section{Fixed And Growth Mindset}

Stanford psychologist and researcher, Dweck, has elaborated on what and how a fixed mindset contributes to a lack of learning and success (add several). Dweck states,

In my research in collaboration with my graduate students, we have shown that what students believe about their brains -- whether they see their intelligence as something that's fixed or something that can grow and change -- has profound effects on their motivation, learning, and school achievement" (2006, retrieved from http://www.nais.org/Magazines-Newsletters/ISMagazine/Pages/Brainology.aspx).

Often, when children stop working in school, parents deal with this by reassuring their children how smart they are. We can now see that this simply fans the flames. It confirms the fixed mindset and makes kids all the more certain that they don't want to try something difficult -- something that could lose them their parents' high regard. (113)

\section{Grit}

In the online college environment, students often give up trying and drop out; sometimes without warning. In order to increase retention, help students persist when challenges arise, and increase learning, faculty may be in a position to create an environment where a growth mindset and grit are fostered. Faculty can help students develop grit and a growth mindset to increase their chances of reaching long-term goals, by internalizing the motivation to persist (Duckworth, Peterson, Matthews, \& Kelly, 2007, p 1089). The Grit scale was developed to measure the characteristics of grit. The scale can be used to help educators teach students to measure and reflect on their own levels of grit. Educators must create learning environments to help students persist and thrive. Grit is one characteristic that can be developed to help college students change their perception; intelligence is fixed.

\section{Intelligence, IQ, Fixed And Growth Mindset}

Academic institutions have relied on intelligence tests and scores to predict achievement, but inborn abilities are not the only factors that account for learning and success. The focus on testing in many universities can undermine both creativity and grit. Dweck (2010) created a growth mindset workshop for seventh graders and randomly assigned participants to one of two groups. One group was asked to read an article focusing on the ability to improve intelligence like a muscle and the other group was deemed the growth mindset cohort and seemed to respond quite favorably to the information. Students must develop those psychological qualities of grit and tenacity and internalize a mindset that includes persevering, and universities are in a position to help. It appears that when teachers teach students how to persist, a growth mindset develops, thus improving grit to overcome any challenges.

\section{CONCLUSION}

The growth mindset can be taught to faculty, students and parents. Growth mindset is changing a student's thinking that intelligence level is not a fixed number and can change. Grit in education is how one can achieve longterm goals by overcoming obstacles and challenges. Duckworth and Dweck collaborated, conducting studies to determine how a fixed belief that failure is permanent could prevent students from academic success. Duckworth concluded that having a "growth mindset" could develop grit. Identifying explanatory style using the Grit assessment is one way to determine where students can put their efforts to learn to persist in the face of academic challenges. Faculty should not focus on making just good grades, but how to challenge that person and teach them to create solutions. In addition, teaching a growth mindset and grit facilitates long-term goals and how to achieve them.

\section{AUTHOR INFORMATION}

Aaron Hochanadel is a full-time faculty member in the School of Business and Management at Kaplan University. $\mathrm{He}$ also serves as a course lead for the class AB299: Associates Capstone in Management. Research interests are education and technology. E-mail: ahochanadel@kaplan.edu. 
Dora CD Finamore is a faculty member at Kaplan University, Northcentral University, and The University of Phoenix. She also serves as curriculum expert in positive psychology. Research interests are education and learning, positive psychology, and child psychology/play therapy. Her recent publications include refereed journals, professional publications, books, and conference presentations focused on learning and motivation, resilience, and leadership. She completed a fellowship in positive psychology and leadership. E-mail: dfinamore@ kaplan.edu.

\section{REFERENCES}

1. Blackwell, L., Trzesniewski, K. H., \& Dweck, C. S. (2007). Implicit theories of intelligence predict achievement across an adolescent transition: A longitudinal study and an intervention. Child Development, $78(1), 246-263$.

2. De Meuse, K. P., Guangrong, D., \& Hallenbeck, G. S. (2010). Learning agility: A construct whose time has come. Consulting Psychology Journal, 62, 119-130.

3. Duckworth, A. (2007). Grit: Perseverance and Passion for Long-Term Goals. Journal Of Personality \& Social Psychology, 92(6), 1087.

4. Duckworth, A. L., Peterson, C., Matthews, M. D., \& Kelly, D. R. (2007). Grit: Perseverance and passion for long-term goals. Journal of Personality and Social Psychology, 92, 1087-1101.

5. Duckworth, A., \& Quinn, P. D. (2009). Development and Validation of the Short Grit Scale (Grit-S). Journal Of Personality Assessment, 91(2), 166-174. doi:10.1080/00223890802634290.

6. Duckworth, A., Quinn, P. D., Lynam, D. R., Loeber, R., \& Stouthamer-Loeber, M. (2011). Role of test motivation in intelligence testing. Proceedings Of The National Academy Of Sciences Of The United States Of America, 108(19), 7716-7720. doi:10.1073/pnas.1018601108.

7. Duckworth. (2013, April). The key to success? Grit [Video File]. Retrieved from http://www.ted.com/talks/angela_lee_duckworth_the_key_to_success_grit\#t-357357.

8. Duckworth, A., \& Eskreis-Winkler, L. (2013). Grit. Observer, 26, (4).

9. Dweck, C. S. (1999). Self-theories: Their role in motivation, personality, and development. Philadelphia: Psychology Press.

10. Dweck, C. S. (2007). The perils and promises of praise. Educational Leadership, 65(2), 34-39.

11. Dweck, C. S. (2007, January 12). The Growth Mindset. Retrieved May 13, 2014, from http://www.mindsetworks.com/webnav/whatismindset.aspx.

12. Dweck, C. S. (2008). Brainology transforming students' motivation to learn. Independent School, 67(2), 110-119.

13. Dweck, C. S. (2009). Can we make our students smarter? Education Canada, 49(4), 56.

14. Dweck, C. S. (2010). Even geniuses work hard. Educational Leadership, 68(1), 16.

15. Dweck, C. S. (2010). Mind sets and equitable education. Principal Leadership. Jan, 10, (5), 26.

16. Frontiers in Psychology [Front Psychol]. (2014, February 03); Vol. 5, pp. 36. Date of Electronic Publication: 20140203 (Print Publication: 2014).

17. Harvard Graduate School of Education. (2011). 'Pathways to Prosperity: Meeting the challenge of preparing young Americans for the $21^{\text {st }}$ century', [online]. http://www.gse.harvard.edu/news events /features/2011/Pathways\%5Fto\%5FProsperity\%5FFeb2011.pdf [Accessed May 2, 2014].

18. Nolen-Hoeksema, S., Girgus, J. S., \& Seligman, M. E. (1986). Learned helplessness in children: A longitudinal study of depression, achievement, and explanatory style. Journal Of Personality And Social Psychology, 51(2), 435-442. doi:10.1037/0022-3514.51.2.435.

19. Perkins-Gough, D. (2013). The Significance of GRIT A Conversation with Angela Lee Duckworth. Educational Leadership, 71(1), 14-20.

20. Peterson, C., \& Seligman, M. E. P. (1984). Causal attribution as risk factor for depression: Theory and research. Psychological Review, 91 347-374.

21. Vandewalle, D. (2012). A Growth and Fixed Mindset Exposition of the Value of Conceptual Clarity. Industrial \& Organizational Psychology, 5(3), 301-305. doi:10.1111/j.1754-9434.2012.01450.x.

22. Winkler-Eskreis, L., Shulman, E. P., Beal, S., \& Duckworth, A. (2014, February). The Grit effect: predicting retention in the military, the workplace, school, and marriage. Frontiers in Psychology. Doi: 10.3389/fpsyg.2014.00036. 